\title{
Primary care consultation liaison and the rate of psychiatric hospitalizations: a countrywide study in Chile
}

\author{
Rafael Sepúlveda, ${ }^{1}$ Pedro Zitko, ${ }^{2}$ Jorge Ramírez, ${ }^{1}$ Niina Markkula, ${ }^{3}$ \\ and Rubén Alvarado ${ }^{1}$
}

Suggested citation Sepúlveda R, Zitko P, Ramírez J, Markkula N, Alvarado R. Primary care consultation liaison and the rate of psychiatric hospitalizations: a countrywide study in Chile. Rev Panam Salud Publica. 2018;42:e138. https://doi.org/10.26633/RPSP.2018.138

ABSTRACT Objectives. To assess the quality of consultation liaison across all primary health care centers in Chile, and its potential relationship with the psychiatric hospitalization rate.

Methods. We carried out a countrywide ecological cross-sectional study on 502 primary health centers in 275 municipalities (87.3\% of total primary health centers in Chile) during 2009. We characterized the presence of consultation liaison using four criteria: availability, frequency, continuity of participants, and continuity across care levels. We also created a dichotomous variable called "optimal consultation liaison" for when all four criteria were met. A quasi-Poisson regression model was used to estimate the rate of hospitalization due to different psychiatric disorders, adjusting by population attributes.

Results. Of the primary health centers, $28.3 \%$ of them had had optimal consultation liaison during the preceding year, concentrated in the poorest and richest municipalities. Continuity of care was the criterion that was met least often (38.3\%). The presence of optimal consultation liaison at the municipal level was associated with fewer psychiatric discharges, with the following incidence rate ratios and 95\% confidence intervals (CIs): schizophrenia, 0.65 (95\% CI: 0.49-0.85); other psychoses, 0.68 (95\% CI: 0.52-0.89); and personality disorders, 0.66 (95\% CI: 0. 49-0.89). Municipalities with optimal consultation liaison showed 2.44 fewer total psychiatric discharges per 10000 inhabitants, although without reaching statistical significance (-0.85 to 5.70).

Conclusions. Using a nationally representative sample, we found that consultation liaison in primary care was associated with having fewer psychiatric hospitalizations. More studies are required to understand the role of each component of consultation liaison.

Keywords Referral and consultation; hospitals, psychiatric; community mental health services; community psychiatry; primary health care; Chile.

\footnotetext{
Universidad de Chile, Escuela de Salud Pública, Santiago de Chile, Chile. Send correspondence to Rafael Sepúlveda at dr. rafaelsepulveda@gmail.com or mariela.segura@ redsalud.gov.cl
}

\footnotetext{
2 King's College London, Health Service and Population Research Department, IoPPN, London, United Kingdom of Great Britain and Northern Ireland.

3 Universidad Diego Portales, Santiago de Chile, Chile.
}

Mental disorders are the second-largest contributor to the burden of years lived with disability (1). There is a large treatment gap in all mental disorders 
(2), and to expand treatment coverage, it is vital to provide treatment for mental disorders in primary care. This can be facilitated by consultation liaison (CL), where a mental health specialist supports the primary care provider who is in charge of the treatment (3), usually by visiting the health center periodically. It is a way for primary and secondary care to communicate with each other, and it is also a fundamental part of the community model in mental health care (4). Moreover, CL increases the capacity of primary care workers to resolve cases at the primary level, and it enhances communication and continuity of care between these two levels (5).

From a public health perspective, mental health services that are better articulated with each other and that effectively incorporate primary health centers are associated with reduced use of more complex resources and lower cost per unit, such as with psychiatric hospitalization $(6,7)$. In particular, the community model in mental health care has been shown to reduce psychiatric emergency visits (8). In addition, intensive case management may reduce the time spent in inpatient care (9).

Some studies looking specifically at the impact of CL have found that it improves mental health outcomes and the adequacy of the treatment received (3). However, the quality of this evidence was considered low, and more substantiation is needed to assess the effectiveness of CL in different groups, and in preventing negative outcomes such as hospitalizations.

This study is set in Chile, where the public mental health care sector reflects the challenges of a middle-income country, despite the country being recently classified as a high-income country (10). At the time of the study, the country had about 17 million inhabitants, with more than $70 \%$ of the population using the public health system (11). The mental health services are provided at the primary care level free of charge, with referral to secondary care if necessary.

This ecological study aimed to assess the quality of psychiatric consultancy across all primary health centers in Chile, as well as the potential relationship that consultancy has with the psychiatric hospitalization rate.

\section{MATERIAL AND METHODS}

We carried out an ecological cross-sectional study gathering information from various data sources.

We surveyed all the public primary health centers of Chile $(\mathrm{N}=575)$ in all the municipalities of the country $(\mathrm{N}=$ 346). Information on type and quality of CL was collected using the EvaRedCom-TMS instrument at the primary health center level. This instrument was developed and validated in Chile and it has been used in several studies related to the evaluation of the community mental health care model (12-14). The EvaRedCom-TMS is composed of three parts. The first part measures availability of mental health resources (e.g., number of units allocated for hospitalization, rehabilitation, outreach care, etc.) and accessibility (e.g., waiting times, distance of heath care centers from locations, cost of transport). The second part measures the level of specialization of mental health care units and was adapted from the International Classification of Mental Health Care instrument (15). The third part includes specific information about the health care for patients with a diagnosis of schizophrenia.

In the context of this study, CL is understood as the meeting of at least one psychiatrist with at least one general practitioner, with the aim of examining patients and clinical records, improving the functioning of the mental health program in the territory of the primary health center, and promoting the continuity of care when patients move between different levels of health care.

The questionnaire encompassed four key aspects of CL: (i) availability of CL (yes or no) at the level of the primary health care center; (ii) frequency of CL (categorized as less than one time per month, monthly, or at least fortnightly); (iii) CL performed regularly by the same psychiatrist (yes or no); and (iv) if a patient was transferred to secondary care, would the person be attended by the same psychiatrist providing the $\mathrm{CL}$ (three categories: never or almost never, almost always, or always).

The survey using EvaRedCom-TMS was performed by trained staff between June 2009 and January 2010 (16). Of the 575 primary health centers (belonging to 346 municipalities), information was collected for 555 primary health centers (291 municipalities), corresponding to a response rate of $96.5 \%$. There was missing data in some variables related to the CL. The final number of primary health centers included in the analysis was 502, equivalent to $87.3 \%$ of all primary health centers available in the country ( $275 \mathrm{mu}$ nicipalities). The details of the field work process and EvaRedCom-TMS are described elsewhere (16). The study was approved by the Ethics Committee of the School of Medicine of the Universidad de Chile.

\section{Exposure: consultation liaison}

The quality of the CL was generated from the questions in the EvaRedCom-TMS instrument as described above. The CL at the primary health center level was considered optimal when the following criteria were met during the preceding 12 months: (a) CL was available, (b) it occurred at least monthly, (c) it was performed by the same psychiatrist, and (d) in the case of patients transferred to the secondary level of care, they would be attended always or almost always by the same psychiatrist providing the consultation. In addition to this dichotomous definition, a three-level quality variable was explored: not available, available but not optimal, and optimal.

\section{Outcome: psychiatric hospitalization rate}

The outcome of the study was the rate of hospitalization at the municipality level. This classic indicator has been used in several studies for evaluating the performance of health services, mainly because it is relatively easy to collect and it also measures resource utilization (17-21). The number of hospitalizations in 2009 was extracted from the national register of hospital discharges, maintained by the Chilean Ministry of Health (available from www.deis.cl). The database has been updated yearly since 2003, and it includes information on any hospitalization occurring in the country, in both private and public institutions. Psychiatric hospitalization was defined as those hospitalizations whose main discharge diagnosis was F00-F69.9, according to the International Classification of Diseases, 10th revision (ICD-10). The hospitalizations were stratified 
into eight categories: organic mental disorders (F00.0-F09.9); substance use disorders (F10.0-F19.9); bipolar disorders (F30.0-F31.9); depressive and other mood disorders (F32.0-F39.9); schizophrenia (F20.0-F20.9); other nonaffective psychotic disorders (F21.0-F29.9); anxiety disorders (F40.0-F49.9); and personality disorders (F60.0-F69.9). Because CL is provided almost exclusively in the public health care network, the analysis considered only discharges from public hospitals.

The population used as the denominator to calculate the rate of hospitalization was extracted from the database of the public National Health Fund (22) and corresponded to all beneficiaries of the public health care sector. Both the population and hospitalizations were limited to persons 15 years old or older.

\section{Confounders}

There is abundant evidence of the relationship between economic deprivation and a higher incidence of psychosocial stress, mental disorders, and psychiatric hospitalization (23-25). Therefore, we included two proxy variables to measure the municipality socioeconomic level. The first one was the proportion of people living below the poverty line in each municipality. The information was extracted from the database of the National Socioeconomic Characterization Survey (CASEN) for 2009. Since 1988, this survey has been carried out routinely every two or three years in Chile. The survey is representative at the national, regional, and municipality level. The total sample for the CASEN 2009 was 246924 people, and its methodological description is available elsewhere (26). The survey defined the poverty line as the amount of money a person needed to access a basic monthly basket of food and goods, which in 2009 was approximately US\$ 117 and US\$ 79 for urban and rural localities, respectively (27). Household per capita autonomous income was used in the calculation.

The second socioeconomic variable included was low educational attainment. This was defined as the percentage of people more than 18 years old who had less than 9 years of formal education. The information was also extracted from CASEN 2009.

In all cases, in line with the complex design of the survey sample, the data on each individual was weighted using the inverse of the probability of selection.

Additionally, data were adjusted for the sex and age distribution of the population in each municipality, since these factors are associated with the risk of being hospitalized for a psychiatric disorder (28). For this purpose, we built two variables using the CASEN survey: the proportion of population who were female, and the proportion of the population between 15 and 55 years old.

\section{Statistical analysis}

For descriptive purposes, the presence of optimal CL was explored at the primary health center level. However, the rate of hospitalization was only available at the municipal level. Therefore, a variable of "optimal CL at municipal level" was created by calculating the proportion of public-health-sector beneficiaries in each municipality who belonged to a primary health center territory with optimal CL. If the proportion was higher than 0.5 , the municipality was coded as 1 , indicating the presence of optimal CL. Otherwise, it was coded as 0 , indicating the absence of optimal CL. It is worth noting that $64 \%$ of the municipalities included in the analysis had only one primary health center, so the classification of the center was equivalent to that of the municipal level.

The availability of optimal CL at primary health centers was estimated, and the presence of its different quality criteria was described. Equity in the distribution of optimal CL was explored by categorizing the municipalities according to the percentage of people living in poverty in four quartiles. The fraction of primary health centers with optimal CL for each quartile is reported.

The association between the presence of optimal CL at the municipal level and the rate of psychiatric hospitalization was explored using quasi-Poisson regression models, adjusting and not adjusting for potential confounders. The results are expressed using absolute terms, i.e., difference of means, and using the incidence rate ratio (IRR); 95\% confidence intervals (CIs) are also reported for all the models. The same analyses were repeated using the threelevel variable of CL quality as was described above. All analyses were performed using $\mathrm{R}$ version 3.0.1 statistical software.

\section{RESULTS}

Information on the poverty rate, educational attainment, and rate of psychiatric hospitalization by municipality is presented in Table 1. The mean percentage of people living under the poverty line across municipalities was 55.4\%, while the mean of low educational attainment was $27.6 \%$.

The overall rate of psychiatric hospitalization was 21.4 per 10000 people (Table 1). Substance use and depressive disorders were the most common reasons for hospitalization, with rates over 5.0 per 10000 people.

CL was available in $62.4 \%$ (95\% CI: $58.2 \%-66.7 \%$ ) of primary health centers (Figure 1). The criterion of optimal CL that was the least often met was continuity of care after referral to secondary care with the same psychiatrist performing the CL $(38.3 \%, 95 \%$ CI: $34.0 \%-42.5 \%)$. The proportion of primary health centers receiving optimal CL was $28.3 \%$ (95\% CI: $24.4 \%-32.2 \%$ ).

Optimal CL was most often available in primary health centers belonging to municipalities in the poorest quartile (41.3\%, 95\% CI: $34.4 \%-48.2 \%)$, followed by the municipalities in the richest quartile $(27.3 \%$, 95\% CI: $18.5 \%-$ $36.0 \%$ ). The second-richest quartile presented the lowest presence of primary health centers with optimal CL (11.6\%, 95\% CI: 5.1\%-18.0\%), while the second-poorest quartile showed an intermediate rate $(20.5 \%, 95 \% \mathrm{CI}$ : $13.1 \%-28.0 \%$ ).

Table 2 presents the incidence rate ratios (IRRs) for hospitalization due to different mental disorders in municipalities with and without optimal CL. Optimal CL was associated with a lower rate of hospitalization for schizophrenia, other psychoses, and personality disorders. Municipalities with optimal CL had 35\% (95\% CI: 15\%-51\%) fewer hospitalizations for schizophrenia and 32\% (95\% CI: $11 \%-48 \%$ ) fewer hospitalizations for other psychoses than did municipalities without optimal CL.

Municipalities with optimal CL had 1.01 (95\% CI: 0.42-1.61) fewer hospitalizations per 10000 people due to schizophrenia than did municipalities without optimal CL, according to the adjusted model. Total hospitalizations were 2.44 fewer per 10000 people in municipalities with optimal CL, but this finding was not statistically significant. A similar 
TABLE 1. Description of number of primary health care centers $(N=502)$, educational attainment, poverty rate, and rate of psychiatric hospitalization by municipality $(\mathrm{N}=\mathbf{2 7 5})$, in study of primary care consultation liaison and psychiatric hospitalizations in Chile, 2009

\begin{tabular}{lcccc}
\hline Characteristic & Mean & Median & Minimum & Maximum \\
\hline Number of primary health centers & 1.8 & 1 & 1 & 12 \\
Percentage of population older than 18 years with less than & $27.6 \%$ & $26.6 \%$ & $1.0 \%$ & $57.0 \%$ \\
8 years of schooling & & & & \\
Percentage of people living under the poverty line & $55.4 \%$ & $57.2 \%$ & $14.1 \%$ & $79.3 \%$ \\
Psychiatric hospitalization rate (per 10 000 inhabitants) & & & & \\
All psychiatric causes & 21.39 & 15.57 & 0.00 & 126.58 \\
Substance use disorder & 5.95 & 3.80 & 0.00 & 38.19 \\
Depression & 5.81 & 2.88 & 0.00 & 92.06 \\
Anxiety disorder & 2.87 & 1.40 & 0.00 & 28.64 \\
Schizophrenia & 2.67 & 2.08 & 0.00 & 49.56 \\
Personality disorder & 1.27 & 0.69 & 0.00 & 12.46 \\
Bipolar disorder & 1.00 & 0.49 & 0.00 & 7.59 \\
Organic mental disorders & 0.92 & 0.48 & 0.00 & 10.08 \\
Other psychoses & 0.88 & 0.49 & 0.00 & 9.62 \\
\hline
\end{tabular}

Source: Prepared by the authors, using: (1) the database of the National Socioeconomic Characterization Survey (CASEN) for 2009; (2) the national hospital discharge registry of the Chilean Ministry of Health; and (3) the databases of the number of beneficiaries of the public National Health Fund.

FIGURE 1. Presence (percentage) of four quality criteria of consultation liaison (CL) and of optimal CL in 502 Chilean primary health care centers belonging to 275 municipalities, 2009a

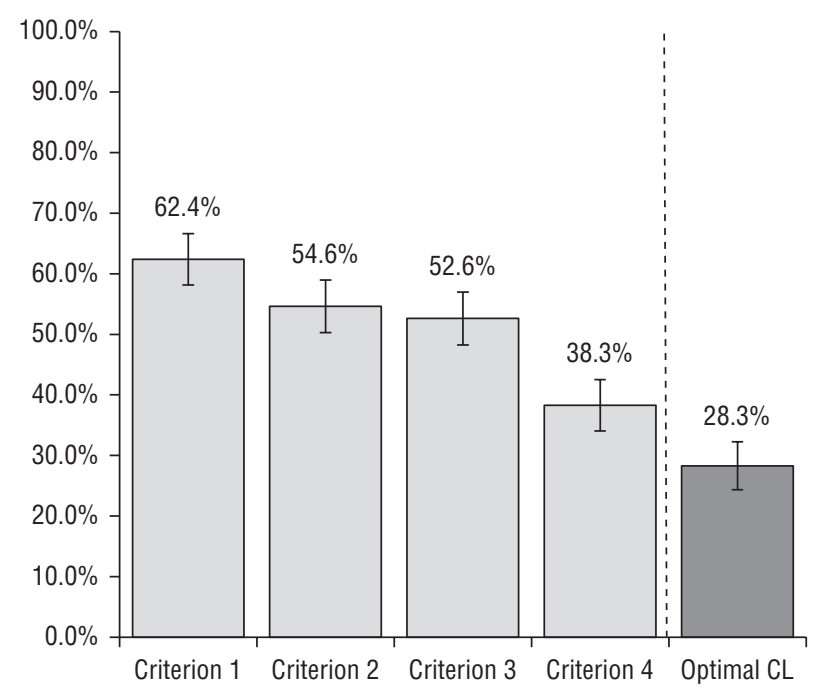

Source: Prepared by the authors, using study data.

${ }^{a}$ Criterion $1=C L$ was available at the primary health care center; Criterion $2=\mathrm{CL}$ occurred during the past month; Criterion $3=\mathrm{CL}$ was performed by the same psychiatrist; Criterion $4=$ in the case of referral to secondary care, patients would always or almost always be attended by the same psychiatrist of the CL; optimal $\mathrm{CL}=$ Criterion $1+$ Criterion $2+$ Criterion $3+$ Criterion 4.

trend (also not statistically significant) of fewer discharges was observed for the rest of the mental disorders, except for depression.

Figure 2 shows the IRRs for hospitalization due to different mental disorders in municipalities without CL $(\operatorname{IRR}=1.00)$, with suboptimal CL, and in comparison with the categories of without CL and of suboptimal CL.

\section{DISCUSSION}

In this countrywide study of Chile, we found that consultation liaison was available in roughly two-thirds of the primary health centers, while optimal CL was available in fewer than onethird of them. The poorest and richest municipalities had the greatest availability of optimal CL. The availability of optimal CL was associated with a lower rate of hospitalization for schizophrenia, other psychoses, and personality disorders, although a more complex relationship was seen when the quality of $\mathrm{CL}$ was included in the analysis. When the municipalities were categorized into three groups and "no CL" was separated from "suboptimal CL," the latter category showed a higher rate of hospitalizations.

There are few antecedents to compare this situation with other countries in Latin American and the Caribbean. Reports of the World Health Organization available for the area indicate that the percentage of primary health care physicians who have interacted at least once a year with a mental health professional ranged between 21\% and $50 \%$ in Argentina (29) and Uruguay (30) and between $51 \%$ and $80 \%$ in Costa Rica (31). However, this annual interaction is very different from the definition of consultation liaison used in our study.

In the case of Chile, the most recent reporting, carried out in 2012, indicated that between $84 \%$ and $91 \%$ of primary health centers interacted at least once a month with mental health professionals, mainly through consultancies (32). This finding shows an improvement since the year of our field work (2009), when $54.6 \%$ of primary health centers reported CL at least every month. However, only $32 \%$ to $52 \%$ of physicians participated in the consultation liaison in 2012 (32).

The distribution of the results according to the socioeconomic level of the municipalities showed better results for the two extremes: poorest and richest areas. This phenomenon could be explained by strategies of targeting resources on poorer areas and of maintaining stable flows of resources to richer areas. There 
TABLE 2. Incidence rate ratio (IRR) of psychiatric hospitalization and difference of means (DM) of psychiatric hospitalizations per 10000 people in 2009 in Chilean municipalities $(N=275)$ with and without optimal consultation liaison, with $95 \%$ confidence intervals (Cls) ${ }^{\mathrm{a}}$

\begin{tabular}{|c|c|c|c|c|c|c|c|c|}
\hline \multirow[t]{2}{*}{ Mental disorder } & \multicolumn{2}{|c|}{ Crude IRR } & \multicolumn{2}{|c|}{$\begin{array}{c}\text { IRR adjusted for poverty, } \\
\text { educational level, age, and sex }\end{array}$} & \multicolumn{2}{|c|}{ Crude DM } & \multicolumn{2}{|c|}{$\begin{array}{c}\text { DM adjusted for poverty, } \\
\text { educational level, age, and sex }\end{array}$} \\
\hline & IRR & $95 \% \mathrm{Cl}$ & IRR & $95 \% \mathrm{Cl}$ & $\mathrm{DM}$ & $95 \% \mathrm{Cl}$ & DM & $95 \% \mathrm{Cl}$ \\
\hline Total discharges & 0.85 & 0.68 to 1.06 & 0.84 & 0.68 to 1.04 & 3.53 & -0.54 to 7.60 & 2.44 & -0.85 to 5.7 \\
\hline Depression & 1.16 & 0.81 to 1.64 & 1.13 & 0.83 to 1.54 & -0.49 & -1.95 to 0.95 & -0.47 & -1.65 to 0.70 \\
\hline Anxiety disorder & 0.83 & 0.57 to 1.20 & 0.76 & 0.55 to 1.04 & 0.61 & -0.02 to 1.25 & 0.30 & -0.27 to 0.87 \\
\hline Schizophrenia & 0.65 & 0.50 to 0.85 & 0.65 & 0.49 to 0.85 & 1.14 & 0.41 to 1.87 & 1.01 & 0.42 to 1.61 \\
\hline Bipolar disorder & 0.83 & 0.62 to 1.10 & 0.80 & 0.59 to 1.07 & 0.21 & -0.11 to 0.53 & 0.19 & -0.08 to 0.46 \\
\hline Organic mental disorders & 0.86 & 0.62 to 1.21 & 0.86 & 0.61 to 1.20 & 0.16 & -0.1 to 0.43 & 0.10 & -0.13 to 0.34 \\
\hline Other psychoses & 0.71 & 0.54 to 0.93 & 0.68 & 0.52 to 0.89 & 0.29 & 0.07 to 0.52 & 0.25 & 0.06 to 0.44 \\
\hline
\end{tabular}

Source: The analysis was performed on a database that merged information from: (1) a survey carried out with Chilean primary health care centers; (2) the database of the National Socioeconomic Characterization Survey (CASEN) for 2009; (3) the national hospital discharge registry of the Chilean Ministry of Health; and (4) the databases of the number of beneficiaries of the public National Health Fund.

${ }^{a}$ Statistically significant IRRs (the $\mathrm{Cl}$ does not include 1.00) and statistically significant DM values (the $\mathrm{Cl}$ does not include 0.00 ) are highlighted with a darker background.

FIGURE 2. Incidence rate ratio (IRR) of psychiatric hospitalization due to different mental disorders, adjusted by population education, poverty, age, and sex, for Chilean municipalities ( $N=275)$, according to three categories of consultation liaison (CL), 2009a

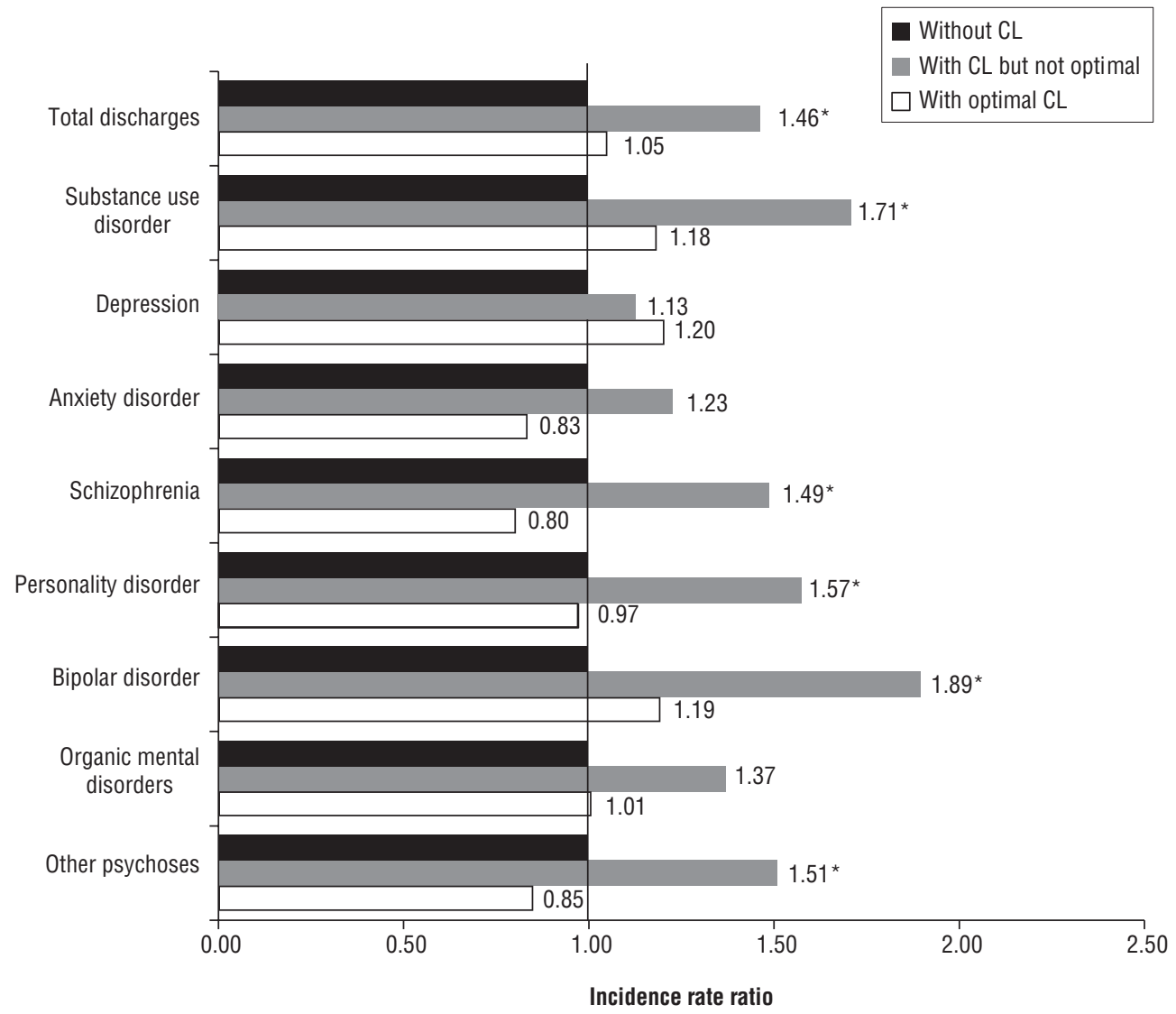

Source: The analysis was performed on a database that merged information from: (1) a survey carried out with Chilean primary health care centers; (2) the database of

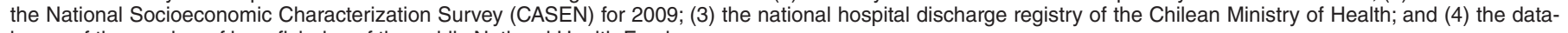
bases of the number of beneficiaries of the public National Health Fund.

a The category of "without CL" is used as the reference (i.e., IRR $=1.00$ ); * indicates p value $<0.05$. 
is also more availability of specialists in urban areas, where most richer municipalities are located (33). It seems that the "inverse care law" described by Tudor in 1971 (34), under which "availability of good medical care tends to vary inversely with the need of the population served," has been partially tackled by the strategy of CL in Chile.

In our study, optimal CL showed an association with fewer hospitalizations for schizophrenia, other psychoses, and personality disorders. These results are in agreement with other ecological studies. In a classic study, Tyrer et al. (6) described a model of collaborative mental health care between primary and specialized care in Nottingham, United Kingdom, which included various forms of contact between the two levels. During the eight-year study period, the rate of psychiatric hospitalizations fell by $30 \%$ in the area where the development of the model was done earlier and more systematically, and only a $9 \%$ in the rest of Nottingham.

A 2010 article by van der FeltzCornelis et al. (35) compared usual care with care that included CL in primary care, through a meta-analysis of 10 randomized controlled trials, which included a total of 3408 patients with somatoform disorder or depressive disorder. Those researchers found a positive impact for CL, with lower rates of utilization of specialized mental health services, including psychiatric hospitalization. However, none of the studies assessed by van der Feltz-Cornelis et al. was carried out in a low- or middleincome country.

Our results also show a relationship between hospitalization rates due to psychiatric conditions and different levels of CL quality. It is remarkable that suboptimal CL showed higher rates of hospitalization compared with no CL, reaching statistical significance for total discharges and almost all mental disorders. Moreover, when compared with the absence of CL, optimal CL did not show a statistically significant reduction in hospitalizations.

It is unclear why suboptimal CL would result in a higher hospitalization rate than the absence of CL. If health centers with suboptimal CL are recently implementing this policy, one could expect an increase in detection of cases that previously were not receiving any psychiatric care. Moreover, if the CL is implemented in an irregular and infrequent manner, it might result in hospitalizing patients because there is no reliable outpatient care system and hospitalization is considered a health care solution for more difficult cases.

It could be expected that over time these problems would diminish as the CL becomes more consolidated and both health care providers and patients trust the system more. This hypothesis is consistent with findings of other authors who have shown that the benefits of different elements of community mental care models could be achieved after a period of increasing utilization of services $(8,36,37)$. To confirm this theory, it would be necessary to examine whether the profile of hospitalized patients is similar in contexts where optimal consultation liaison is and is not available.

It is important to consider that other characteristics of the CL may influence its effectiveness. For instance, some key competencies of the consulting psychiatrist have been outlined in the literature. These include the ability to understand the context of primary health care; to provide clinical support that meets the needs of the primary care practitioner; and to provide training to primary care practitioners so they can increase their skills in detecting and treating mental disorders (38).

Overall, CL can be seen as a part of an effort to improve the performance of the community mental health model of care. In this case, the specific role of CL is related to the integration of mental health into the general health system, the generation of territorial coordination structures, and continuity in the attention to any mental health problem (39).

\section{Study limitations}

This study has certain limitations. Firstly, given its ecological and cross-sectional nature, causal inference is restricted. The results of hospitalizations seen in the year of the study could be the product of accumulated exposure in previous years. Moreover, the lack of observations over time limit our interpretation regarding the impact of different levels of quality of CL on the hospitalization rate.

Secondly, we are not adjusting the analysis for important confounders that could be related to hospital discharges, such as the availability of psychiatric beds for each primary health center. However, even if health centers with optimal CL had fewer psychiatric beds available, this would not explain a higher rate of hospitalizations found in centers with suboptimal CL. Nevertheless, we cannot exclude the influence of possible confounders on the outcome, and future research should use controlled study settings to examine the impact of psychiatric consultation liaison specifically.

\section{Conclusions}

This study provides evidence on the effectiveness of consultation liaison in the context of a Latin American middle-income country that is implementing a policy to promote the community mental health model (40). The study found a reduction of hospitalizations due to some mental disorders that was associated with the availability of optimal CL in the primary health center. However, suboptimal CL seemed to have the opposite impact.

The ecological nature of the study, and possible confounders that could not be controlled for, should be considered when interpreting the results and when planning future research. A wider range of outcomes should be explored, using other epidemiological approaches. More studies also are necessary to determine whether an expansion of the strategy of CL should be driven by improving national coverage or assuring the quality of the liaison.

Acknowledgments. We acknowledge the staff of all the primary health care centers that completed the survey and answered our additional inquiries.

Funding. This project was partially funded by the National Commission for Scientific and Technological Research (CONICYT) (FONIS SA08I20033).

Conflicts of interest. The authors declare no conflict of interest.

Disclaimer. Authors hold sole responsibility for the views expressed in the manuscript, which may not necessarily reflect the opinion or policy of the RPSP/ PAJPH or PAHO. 


\section{REFERENCES}

1. Whiteford HA, Degenhardt L, Rehm J, Baxter AJ, Ferrari AJ, Erskine HE, et al. Global burden of disease attributable to mental and substance use disorders: findings from the Global Burden of Disease Study 2010. Lancet. 2013;382(9904):1575-86.

2. Wang PS, Angermeyer M, Borges G, Bruffaerts R, Tat Chiu W, DE Girolamo G, et al. Delay and failure in treatment seeking after first onset of mental disorders in the World Health Organization's World Mental Health Survey Initiative. World Psychiatry. 2007;6(3):177-85.

3. Gillies D, Buykx P, Parker AG, Hetrick SE. Consultation liaison in primary care for people with mental disorders. Cochrane Database Syst Rev. 2015 Sep 18;(9):CD007193. doi: 10.1002/14651858. CD007193.pub2.

4. Thornicroft G, Deb T, Henderson C. Community mental health care worldwide: current status and further developments. World Psychiatry. 2016;15(3):276-86.

5. Zeidler Schreiter E, Pandhi N, Fondow MDM, Thomas C, Vonk J, Reardon CL, et al. Consulting psychiatry within an integrated primary care model. J Health Care Poor Underserved. 2013;24(4):1522-30.

6. Tyrer P, Ferguson B, Wadsworth J. Liaison psychiatry in general practice: the comprehensive collaborative model. Acta Psychiatr Scand. 1990;81(4):359-63.

7. Jenkins R, Kessler M, Riba M, Gunn J, Kauye F. Public health aspects of integration of mental health into primary care services. In: Ivbijaro G, ed. Companion to primary care mental health. London: Wonca and Radcliffe Publishing; 2012: 97-115.

8. Zitko P, Ramírez J, Markkula N, Norambuena P, Ortiz AM, Sepúlveda R. Implementing a community model of mental health care in Chile: impact on psychiatric emergency visits. Psychiatr Serv. 2017;68(8):832-8

9. Burns T, Catty J, Dash M, Roberts C, Lockwood A, Marshall M. Use of intensive case management to reduce time in hospital in people with severe mental illness: systematic review and meta-regression. BMJ. 2007;335(7615):336.

10. The World Bank. World Bank country and lending groups. Available from: data.worldbank.org/about/countryclassifications/a-short-history Accessed 21 May 2018.

11. Becerril-Montekio V, Reyes JD, Manuel A. Sistema de salud de Chile. Salud Publica Mex. 2011 Jan;53(Suppl 2):s132-s142.

12. Alvarado R. Elaboración y validación de instrumento que describe y caracteriza las redes de servicios de salud mental para personas que padecen esquizofrenia. Rev Chil Salud Publica. 2007;11(3):117-26.

13. Zitko P, Ramírez J, Norambuena P, Ortiz AM, Sepúlveda R, Alvarado R. Informe técnico final. Proyecto FONIS SM12 | 2025: asociación entre el desarrollo del Modelo Comunitario de Atención en Salud Mental (MCASM) y la tasa de consultas de urgencia y egresos hospitalarios por causa psiquiátrica. Santiago de Chile: Fondo Nacional de Investigación y Desarrollo en Salud - CONICYT - MINSAL; 2014.

14. Ramírez J, Ortiz A, Zitko P, Norambuena P, Sepúlveda R, Libuy J, et al. Informe final proyecto FONIS SM14/0011: asociación entre el desarrollo del modelo comunitario de atención en salud mental de la red asistencial y mejoría en la calidad de vida de personas que ingresan al programa integral de salud mental en atención primaria. Santiago de Chile: Fondo Nacional de Investigación y Desarrollo en Salud CONICYT - MINSAL; 2017.

15. de Jong A. Development of the International Classification of Mental Health Care (ICMHC). Acta Psychiatr Scand Suppl. 2000;405:8-13.

16. Alvarado R, Minoletti A, Aliste F, Sepúlveda R, Madariaga C, Caro J. Informe técnico final. Proyecto FONIS SA08 |20033: evaluación de las redes de atención para personas con primer episodio de esquizofrenia, en Chile. Santiago de Chile: Fondo Nacional de Investigación y Desarrollo en Salud - CONICYT MINSAL; 2010.

17. Dietzen LL, Bond GR. Relationship between case manager contact and outcome for frequently hospitalized psychiatric clients. Hosp Community Psychiatry. 1993;44(9):839-43.

18. McGrew JH, Bond GR, Dietzen L, Salyers $\mathrm{M}$. Measuring the fidelity of implementation of a mental health program model. J Consult Clin Psychol. 1994;62(4):670-8.

19. Brekke JS, Long JD, Nesbitt N, Sobel E. The impact of service characteristics on functional outcomes from community support programs for persons with schizophrenia: a growth curve analysis. J Consult Clin Psychol. 1997;65(3):464-75.

20. Brekke JS, Ansel M, Long J, Slade E, Weinstein M. Intensity and continuity of services and functional outcomes in the rehabilitation of persons with schizophrenia. Psychiatr Serv. 1999;50(2):248-56.

21. Bond GR, Salyers MP. Prediction of outcome from the Dartmouth Assertive Community Treatment Fidelity Scale. CNS Spectr. 2004;9(12):937-42.

22. Fondo Nacional de Salud. Bases de datos, informes, estudios y documentos. Available from: https://www.fonasa. $\mathrm{cl} /$ sites/fonasa/institucional/archivos Accessed 21 May 2018.

23. Flisher AJ, Lund C, Funk M, Banda M, Bhana A, Doku V, et al. Mental health policy development and implementation in four African countries. J Health Psychol. 2007;12(3):505-16

24. Lund C, Breen A, Flisher AJ, Kakuma R, Corrigall J, Joska JA, et al. Poverty and common mental disorders in low and middle income countries: a systematic review. Soc Sci Med. 2010;71(3):517-28.

25. Patel V, Lund C, Hatherill S, Plagerson S, Corrigall J, Funk M, et al. Mental disorders: equity and social determinants. In: Blas E, Sivasankara Kurup A, eds.
Equity, social determinants and public health programmes. Geneva: World Health Organization; 2010:115-34.

26. Ministerio de Planificación. CASEN 2009. Informe metodológico. Available from: http://observatorio. ministeriodesarrollosocial.gob.cl/ layout/doc/casen/metodologia_2009 504de6beb0fd4.pdf Accessed 21 May 2018.

27. Ministerio de Desarrollo Social. Metodología del diseño muestral y factores de expansión Encuesta de Caracterización Socioeconómica Nacional. Available from: http://observatorio. ministeriodesarrollosocial.gob.cl/layout/ doc/casen/Informe Diseno Muestral Revision_13sep12.pdf Accessed 21 May 2018.

28. Granmegna S G, Lora L R, Ahumada F P. Análisis base de datos unidad de hospitalización de corta estadía (UHCE). Psiquiatría Hospital Dr. Sótero del Río. Rev Chil Neuropsiquiatr. 2006; 44(1):23-38.

29. Organización Mundial de la Salud. Sistema de salud mental en 10 provincias argentinas: Catamarca, Chubut, Corrientes, Jujuy, Mendoza, Río Negro, Salta, San Juan, Tierra del Fuego, Tucumán. Available from: http://www.who.int/mental health/who_aims_country_reports / argentina_who_aims_report_spanish. pdf?ua=1 Accessed 21 May 2018.

30. World Health Organization. WHOAIMS report on mental health system in Uruguay. Available from: http://www. who.int/mental_health/uruguay_who_ report.pdf?ua=1 Accessed 21 May 2018.

31. Pan American Health Organization; World Health Organization; Ministry of Health of Costa Rica; Social Security Institution of Costa Rica. WHO-AIMS report on mental health system in Costa Rica. 2008; Available from: http://www.who.int/ mental_health/costa_rica_who_aims_report_english.pdf Accessed 21 May 2018.

32. Universidad de Chile, Facultad de Medicina, Escuela de Salud Pública Dr. Salvador Allende Gossen. Sistema de salud mental en Chile. Segundo informe. Available from: http://www.who.int/ mental_health/who_aims_country reports/who_aims_report_chile.pdf Accessed 21 May 2018.

33. Daniels ZM, Vanleit BJ, Skipper BJ, Sanders ML, Rhyne RL. Factors in recruiting and retaining health professionals for rural practice. J Rural Health. 2007;23(1):62-71.

34. Hart JT. The inverse care law. Lancet. 1971; 297(7696):405-12.

35. van der Feltz-Cornelis CM, Van Os TWDP, Van Marwijk HWJ, Leentjens AFG. Effect of psychiatric consultation models in primary care: a systematic review and meta-analysis of randomized clinical trials. J Psychosom Res. 2010 Jun;68(6):521-33.

36. Malone D, Newron-Howes G, Simmonds S, Marriot S, Tyrer P. Community mental health teams (CMHTs) for people with severe mental illnesses and disordered 
personality. Cochrane Database Syst Rev. 2007 Jul 18;(3):CD000270.

37. Wierdsma A, Poodt $H$, Mulder C. Effects of community-care networks on psychiatric emergency contacts, hospitalisation and involuntary admission. J Epidemiol Community Health. 2007;61(7):613-8.

38. Blashki G, Selzer R, Judd F, Hodgins G, Ciechomski L. Primary care psychiatry: taking consultation-liaison psychiatry to the community. Australas Psychiatry. 2005;13(3):302-6.

39. Ministerio de Salud. Orientaciones técnicas: consultorías en salud mental. Available from: http://www.minsal.cl/wp-content/uploads/2015/09/ OT-CONSULTORIAS-EN-SALUDMENTAL.pdf Accessed 21 May 2018.

40. Ministerio de Salud. Plan Nacional de Salud Mental 2017-2025. Available from: http://www.minsal.cl/wp-content/ upload s / 2017 / 12 / P D F - P L A N NACIONAL-SALUD-MENTAL-2017-A2025.-7-dic-2017.pdf Accessed 21 May 2018.

Manuscript received on 7 March 2018. Revised version accepted for publication on 7 May 2018
RESUMEN

\section{Las consultorías de salud mental en atención primaria y la tasa de hospitalización psiquiátrica: estudio nacional en Chile}

\author{
Palabras clave
}

Objetivos. Evaluar la calidad de las consultorías de salud mental en todos los centros de atención primaria de salud en Chile y su posible relación con la tasa de hospitalización psiquiátrica.

Métodos. Se llevó a cabo un estudio transversal ecológico a nivel nacional sobre los 502 centros de atención primaria de salud en 275 municipios (87,3 \% del total de los centros de atención primaria de salud en Chile) durante el 2009. Las consultorías de salud mental se caracterizaron por medio de cuatro criterios: disponibilidad, frecuencia, continuidad de los participantes y continuidad en los distintos niveles de atención. Además, se creó una variable dicótoma llamada "consultoría óptima" para cuando se cumplían los cuatro criterios. Se utilizó un cuasimodelo de regresión de Poisson para calcular la tasa de hospitalización a causa de distintos trastornos psiquiátricos, ajustada por los atributos de la población.

Resultados. De los centros de atención primaria de salud, el 28,3 \% había presentado consultorías óptimas durante el año anterior, concentradas en los municipios más pobres y más ricos. La continuidad de la atención fue el criterio que se cumplió con menos frecuencia $(38,3 \%)$. La presencia de consultorías óptimas a nivel municipal estuvo asociada con menos altas médicas psiquiátricas, con la siguiente razón de tasa de incidencia e intervalos de confianza (IC) del $95 \%$ : esquizofrenia, 0,65 (IC del 95\%: 0,49-0,85); otras psicosis, 0,68 (IC del 95\%: 0,52-0,89); y trastornos de la personalidad, 0,66 (IC del 95\%: 0,49-0,89). Los municipios con consultorías óptimas registraron 2,44 menos altas médicas psiquiátricas totales por 10000 habitantes, aunque sin alcanzar significación estadística $(-0,85$ a 5,70$)$.

Conclusiones. Por medio de una muestra representativa a nivel nacional, encontramos que las consultorías de salud mental en centros de atención primaria de salud estaban asociadas con la disminución de hospitalizaciones psiquiátricas. Se requieren más estudios para comprender la función de cada componente de las consultorías de salud mental.

Derivación y consulta; hospitales psiquiátricos; servicios comunitarios de salud mental; psiquiatría comunitaria; atención primaria de salud; Chile. 
RESUMO

Consultoria em saúde mental na atenção primária e taxa de internação psiquiátrica: estudo nacional no Chile

Objetivos. Avaliar a qualidade da consultoria em saúde mental nos centros de atenção primária à saúde e possível relação com a taxa de internação psiquiátrica.

Métodos. Um estudo de delineamento transversal ecológico foi conduzido em nível nacional em 502 centros de atenção primária à saúde $(87,3 \%$ do número total no país) em 275 municípios no Chile em 2009. A prática de consultoria em saúde mental foi caracterizada de acordo com quatro critérios: disponibilidade, frequência, continuidade dos participantes e continuidade nos níveis de atenção. Também foi criada uma variável dicotômica, denominada "consultoria ideal", quando os quatro critérios eram satisfeitos. Foi usado um modelo de regressão de quase-Poisson para estimar a taxa de internação por diferentes transtornos psiquiátricos, ajustada segundo as características da população.

Resultados. Ao todo, 28,3\% dos centros de atenção primária à saúde tiveram uma prática de consultoria ideal no ano anterior, concentrada nos municípios pertencentes aos quartis mais pobre e mais rico. A continuidade da atenção foi o critério satisfeito com menor frequência (38,3\%). A prática de consultoria ideal ao nível de município foi associada a um número menor de altas psiquiátricas, com as seguintes razões de taxas de incidência e intervalos de confiança de 95\% (IC 95\%): 0,65 para esquizofrenia (IC 95\% 0.49-0.85); 0,68 para outras psicoses (IC 95\% 0.52-0.89) e 0,66 para transtornos de personalidade (IC 95\% 0.49-0.89). Os municípios com prática de consultoria ideal tiveram 2,44 menos altas psiquiátricas por 10 mil habitantes, embora não seja estatisticamente significativo (-0.85 a 5,70).

Conclusões. O estudo de uma amostra representativa da população nacional revelou que a consultoria em saúde mental na atenção primária esteve associada a um número menor de internações psiquiátricas. Outros estudos são necessários para entender o papel de cada componente da consultoria em saúde mental.

Palavras-chave Encaminhamento e consulta; hospitais psiquiátricos; serviços comunitários de saúde mental; psiquiatria comunitária; atenção primária à saúde; Chile. 